\title{
Resensi
}

\section{Penyumbang Devisa yang selalu Terpinggirkan: Potret Pedagang Kakilima Perkotaan}

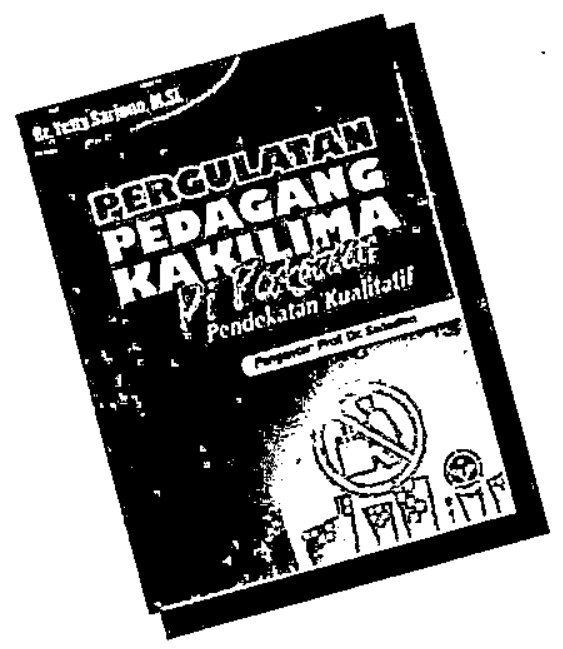

$\mathrm{D}$ i berbagai kota dunia tidak hanya di In donesia, pedagang kaki lima (PKL) senantiasa menempati posisi pinggiran, terutama dalam kebijakan pembangunan perkotaan. Dalam konteks indonesia hampir seluruh pemerintah daerah tak pernah menganggap atau memanusiawikan para PKL ini secara wajar. Dalam kaca mata pemerintah daerah, PKL tak lebih hanya mengotori lingkungan, oleh karena itu tak jarang, ketika ada kunjungan pejabat negara, mereka pun "disembunyikan" agar tidak mengganggu pandangan. Setelah perhelatan para tamu selesai mereka kembali menggelar dagangannya, demikian seterusnya secara rutin. Sikap demikian ini yang menyebabkan mereka harus bergulat - keras karena "hidup" mereka banyak tergantung pada "kebaikan hati" pemerintah kota.

\author{
Judul :Pergulatan Pedagang Kakilima \\ di Perkotaan: Pendekatan \\ Kualitatif
}

Penulis :Dr. Yetty Sarjono, M.Si

Pengantar:Prof.Dr. Salladien

Penerit :Muhammadiyah UniversityPress (UMS Press), Surakarta.

Terbit : Agustus 2005

Tebal $: 251+x v i i$

Dari banyaknya pengalaman pahit yang mereka alami selama ini, dapat disimpulkan, kebijakan pemerintah daerah selama ini hanya melihat sebelah mata sektor informal ini. Dan itu berarti model kebijakan yang dibangun masih elitis yang berorientasi pada usaha-usaha berskala besar seperti mal, supermarket, pasar modern, dan lain-lain.

Kalau disederhanakan, model kebijakan pembangunan perkotaan selama ini masih tidak berpihak kepada usaha kecil seperti pedagang kaki lima îni.

Uniknya, kendati kehadiran mereka dianggap "haram". dan terus dikalahkan dalam policy pembiangunan kota, namun usaha PKL ini terus tumbuh dan berkembang, bahkan semakin sulit dibendung jumlahnya. Dari data yang dicatat Yetty Sarjono___penulis buku ini (hlm.1) di Surakarta jumlah pedagang kakilima bertumbuh rata-rata diatas $13 \%$ per tahun. 
Pertumbuhan para PKL ini berjalan linier dengan pertumbuhan kota dan industri perdagangan skala besar di perkotaan, seperti hadirnya swalayan, mal, super market dan pasar-pasar baik modern maupun tradisional.

Tentu saja, diakui penulis buku ini jumlah mereka yang semakin banyak jelas menimbulkan berbagai masalah sosial seperti menyita badan jalan, trotoar, pojokpojok jalan, seputar "emper" mal, super market, sisi perkantoran, mengganggu keamanan, dan lain-lain. Akhimya, pedagang kakilima pun kini bak Coca Cola, apa saja, siapa saja, dimana saja, kapan saja bisa berdagang kakilima.

\section{Haruskah Dimusuhi ?}

Pertanyaan mendasar yang perlu dijawab adalah, haruskah mereka dimusuhi terus menerus, atau bagaimana seharusnya mereka diperlakukan ?

Dari penelitian penanganan terhadap sektor informal di berbagai kota dunia seperti Manila, Kordoba, Jakarta, Kumasi, Lagos, Free Town dan lain-lain (studi ILO) terbukti, bahwa PKL bukanlah tanpa kontribusi terhadap sebuah kota bahkan sebuah negara. Apalagi dari sekian banyak alasan mengapa mereka memilih hidup menjadi PKL tak lain agar tidak menganggur yang berarti menimbulkan multiflier effect, seperti akan membebani keluarga, masyarakat, pemerintah dan seterusnya. Pilihan itu pun kalau mau diakui secara jujur, tidak melulu negatif, banyak juga nilai positifnya. Tinggal tergantung, solusi apa yang tepat untuk mereka?

Dari studi buku ini dengan sampel kota Surakarta, sangat jelas terlihat, bahwa pedagang kakilima bukanlah musuh yang harus disingkirkan atau dibunuh. Justru sebaliknya, dalam menghadapi para PKL harus dengan bijaksana dan terkonsep. Penulis buku ini juga membandingkan, dari pengalaman yang terjadi di negara Venezuela (David C.C.,1994) terbukti; jika mereka terus dimusuhi, dikalahkan dan jauh dari sikap akomodatif dan aspiratif, maka justru akan menimbulkan masalah baru. Intinya, cara-cara demikian bukanlah solusi terbaik. Secara tegas David C.C. mengatakan, apapun yang dilakukan oleh pejabat pemerintah kota tidak akan berhasil apabila kebijakan yang dikembangkan tidak berpihak kepada PKL itu sendiri (terutama bila masih represif). Ditambahkan, di Mexico kebijakan yang tidak berpihak kepada PKL ini justru terbukti gagal, karena pemerintah kota hanya membuat kebijakan dari satu sudut pandang. Bahkan para PKL di Mexico mampu menggegerkan suasana politik yaitu dengan memboikot penyelenggaraan Pilkada yaitu dengan cara tidak aktif memilih.

Disarankan; jika pemerintah kota ingin berhasil dalam membangun kota, sebaiknya justru dengan model CDS (City Development Strategy), yaitu sebuah model pendekatan kelembagaan yang melibatkan seluruh komponen kota secara bersama-sama untuk membuat pilihan strategi demi masa depan kotanya (hlm.11).

Secara lebih konkret policy yang bisa dilakukan dalam menangani PKL jika merujuk pada studi-studi yang pernah dilakukan seperti studi Robert Ch.Rice (1997) menyimpulkan, bahwa terdapat - hubungan yang sangat erat (simbiosis mutualisme) antara sektor formal dengan sektor informal, di samping juga adanya hubungan yang sangat erat antara sub-sub. sektor informal lainnya. Kesimpulan studi lain didapat dari penelitian Mc Gee (1997), yang mengatakan, bahwa kendati pun sektor informal ini hanya mampu menghasilkan pendapat relatif kecil, namun 
perannya dalam menyerap tenaga kerja (pengangguran) cukup besar. Bahkan bisa dikata, PKL menjadi solusi sederhana mengatasi meledaknya pengangguran baik terdidik maupun awam.

\section{Peningkatan Status}

Studi Yetty Sarjono dalam buku ini akhimya melihat, bahwa apa yang dilakukan oleh pemerintah kota Surakarta relatif baik dan tepat. Artinya, dengan model mirip CDS (City Development Strategy), mampu mengatasi "keliaran" PKL yang tadinya sangat mengganggu pemandangan di berbagai sudut kota menjadi kebijakan yang terpadu (terintegrasi) tertata lebih rapih. Para PKL ini oleh pemerintah kota Surakarta ditingkatkan statusnya dari sektọr informal menjadi diformalkan atau formalitas. Formalitas artinya, mereka secara legal diberi Surat Izin Usaha (HO) dan ditempatkan pada satu tempat menyatu dengan mal, supermarket atau pasar-pasar modem.

Hasil formalitas ini setelah berjalan beberapa lama, terbukti mampu membuat mereka menjadi lebih tenang, lebih tertib dan lebih termotivasi untuk maju dan berkembang lagi. Motivasi yang timbul diantaranya terlihat dari keinginan mereka untuk menambah jumlah barang, modal, atau meningkatkan omset seiring dengan keadaan yang ada. "Dari jumlah pembeli, pada awal-awalnya memang cuma sedikit, tetapi setelah beberapa waktu berjalan, maka terlihat lebih ramai dibanding ketika masih sebagai PKL. Efeknya mereka lalu berupaya meningkatkan omsetnya atau berupaya menambah modalnya melalui bank.(Hlm.125). Yang lebih penting lagi, usaha para PKL yang telah naik statusnya ini (formalitas) terbukti pula menjadi daya tarik tersendiri bagi konsumen dan sinergis dengan induk usaha di tempat tersebut yaitu mal, supermarket, atau pasar modern.

Memang harus diakui, kendati di beberapa tempat telah berhasil menertibkan PKL menjadi lebih baik, namun tetap saja di beberapa tempat lain sejumlah PKL tenus bermunculan. Adalah pekejjaan rumah bagi pemerintah kota untuk terus memprogram agar mereka tertata secara kontinyu dan normal.

Seperti direkomendasikan penulis buku ini (hlm.142), pemerintah harus memberi pengertian terhadap mereka akan arti penting program formalitas ini dilakukan secara terus-menerus sehingga mereka betul-betul sadar, bahwa langkah yang dilakukan pemerintah kota tersebut benar. Sudah barang tentu ada yang senang dengan adanya formalisasi ini, tetapi juga tidak sedikit yang merasa sedih, lantaran ketidaksiapan mereka memasuki sektor formal.

Bagaimanapun sektor informal merupakan sektor yang memainkan peranan penting dalam perekonomian Indonesia, baik pada saat ini maupun masa mendatang karena sifatnya yang mudah dimasuki. Peranan penting tersebut ditunjukkan oleh kenyataan bahwa sektor informal di Indonesia sejak tahun 1999 menyerap 61,99 persen dari seluruh angkatan kerja di Indonesia. Angka ini secara konsisten naik dari tahun ke tahun. Secara mikro pentingnya sektor informal dapat dilihat dari kemampuannya menyediakan barang dan jasa yang relatif murah sehingga dapat diakses oleh masyarakat dari'golongan ekonomi rendah. Namun, harus diakui PKL yang cenderung "liar" juga menjadi faktor pengganggu keindahan, ketertiban, dan keamanan kota.

(Sobirin Malian) 